\title{
BOND AS A SAFE HAVEN DURING MARKET CRASH: EXAMINATION OF COVID-19 PANDEMIC IN ASEAN-5
}

\author{
Gabriela Elvina Dwiastuti Siahaan ${ }^{1}$, Robiyanto Robiyanto ${ }^{2 *}$ \\ ${ }^{1,2}$ Universitas Kristen Satya Wacana, Indonesia \\ Email: 1212017504@student.uksw.edu, ${ }^{2 *}$ robiyanto.robiyanto@uksw.edu \\ *Corresponding author
}

\begin{abstract}
This paper aimed to examine the effectiveness of corporate bonds and government bonds against the stock price fluctuation in ASEAN-5 countries. Using daily data, Quantile Regression method (QREG) was used in this study. With regard to the safe haven effects in corporate bonds and government bonds, we found that corporate and government bonds was an inconsistent safe instrument for different countries. The result of this study indicated that Thailand corporate bond, Singapore corporate bond and Singapore government bond successfully acted as a robust safe haven during crisis. Overall, the findings implied that corporate bonds and government bonds were able to hedge the risks of market shocks related to COVID-19 pandemic.
\end{abstract}

Keywords: COVID-19, ASEAN-5, assets class, safe haven, hedge.

\section{Introduction}

The COVID-19 (Coronavirus), a severe contagious disease was first discovered in Wuhan City of China, December 2019. Just as a domino effect, there's an inevitable slowdown of global economic growth, recession trends among countries which led to a prevailing view among economists that this global health crisis would tumble the world into a global recession (Giles, Greeley, \& Arnold, 2020). This unpredictable event became the reason for an investor to secure their portfolios by switching into an asset that are able to minimize risk exposure (Bulut \& Rizvanoghlu, 2019)

Bonds, on the other hand, would survive as a safe haven for the stocks market when crisis worsened. The stock market is quite sensitive to react toward any changes in the market, while bonds are rather stable or indirectly impacted by forces as it has the bulge on return on assets and liquidity guarantees. Additionally, in the shock of financial market, bonds able to increase the return value and thus, arise as a safe haven properties (Kopyl \& Lee 2016; He, Krishnamurthy, \& Milbradt, 2019). The attractiveness of bond market is given by the risk-free interest rate and offer investors a constant rate of return (Gürtler, Hibbeln, \& Winkelvos, 2016). Finally, making the bonds become the safest investment.

The linkage between the effect of COVID-19 related to financial market has been tried by many experts, including the use of panel data on the return of stock market in China (Al-Awadhi, Alsaifi, AlAwadhi, \& Alhammadi, 2020), economic growth and government intervention (Ashraf, 2020) and how COVID-19 creates a "black swan" event on global market using granger causality and spectral causality
(Morales \& Andreosso-O'Callaghan, 2020). Additionally, several studies such as Cheema and Szulczyk (2020), Akhtaruzzaman, Boubaker, Lucey, and Sensoy (2020) and Ji, Zhang, and Zhao (2020) explained the role of commodities, gold and other assets as a safe haven in a developed countries. In order to fill the gap, this study examined the potential of bonds as a safe portfolio during in developing countries especially the ASEAN market.

Finally, in the context of the ASEAN capital markets, investigation of bond's capacity as safe havens during COVID-19 is still extremely rare to be found, and possibly have never been done. This paper aims to evaluate the role of government and corporate bonds against stock price volatility in the ASEAN-5 (Indonesia, Malaysia, Singapore, Philippines and Thailand) market during COVID-19. The study on concrete consequences of the COVID-19 provides a valuable opportunity to gain insight into drivers of firm value and the working of the equity market.

\section{Asset Class}

Burniske and White (2017) defined an asset class as a group of assets that possess similar fundamental economics and has certain characteristics which distinguish them from those assets outside their asset class. They developed a new theory, classifying assets into four categories. First, an investable asset, which provides sufficient opportunity and liquidity to invest. Secondly, it should have an economic-politic profile distinction based on governance and value. Third, price independency where an asset's fluctuation has a low correlation compared to other assets in terms of return. Lastly, absolute return based on risk. 
Jointly, these categories clarify which assets belongs to in each class. Bonds and equities for example, are considered as a different asset class as they fulfil the requirement of being investable compared to other assets. Compared to equity, bonds tend to have lower volatility and lower risk reward. In terms of economic-political profile, bonds provide a stable periodic payment within a period of time secured by a company's underlying assets. Moreover, its ability to rally in a "risk-off" environment is what makes bonds behave differently in bonds market.

\section{Safe Haven, Hedge, and Diversification}

Bekiros, Boubaker, Nguyen, and Uddin (2017), and Wen and Cheng, (2018) proposed a definition of a safe haven as an instrument that is unrelated or negatively related in respect to the other asset under extreme market circumstances. Similarly, Robiyanto, Wahyudi, and Pangestuti, (2017) define a it as a low-risk investment with high liquidity bought by the investors in order to prevent loss damage. Further down in their work, the most coveted safe haven requisite a negative correlation during a bearish market yet positively correlated during an increase in market. Thereupon, a safe asset holds important roles in the portfolios as their ability to alleviate the impacts of an adverse shock to asset class.

Among the relevant studies, one of the prominent definitions of hedging is a class of assets that has a negative correlation towards other portfolios on average (Shakil, Mustapha, Tasnia, \& Saiti, 2018) and can only be seen as a temporary tactics (Lim \& Cooper, 2015) and as one of the trading strategies on futures market (Šperanda \& Tršinski, 2015). Meanwhile, diversifier assets are any instrument with positive correlation toward other portfolios. Similar to the hedge, the diversifier does not have the power of reducing losses in market crash as the correlation only functioning to hold on average (Ghazali, Lean, \& Bahari, 2015).

\section{Bonds and Safe Haven}

Studies proved that when the market collided, there is a downturn dynamic linkage among the return of stocks and bonds, thus both asset prices move into opposite directions (Lin, Yang, Marsh, \& Chen, 2018). This statement was supported by Dicle and Levendis (2017) to conclude that the co-movement between stock and bonds would be negative during an extreme turmoil, supporting the fact of bonds are a safe haven. Investigating bond's as a potential safe haven, Hou, Khrashchevskyi, and Peltomäki (2019) revealed that bonds only perform as a hedge, at least on average. However, it is important to take a note as other than the compelling features, bonds are still likely to be affected by several risk such as inflation risk, currency risk and other default.

\section{Government Bonds as Safe Haven}

Government bonds apparently a suitable as a safe haven towards the shares (Habib, Stracca, \& Venditti, 2020). As a prominent safe haven, government bonds are able to in intervening the market during turmoil rather than gold (Liu, 2018). Based on above explanation, the hypothesis is constructed as follows:

$H_{l a}$ : Government bonds can act as a safe haven for Indonesia Stock Exchange

$H_{l b}$ : Government bonds can act as a safe haven for the Kuala Lumpur Stock Exchange.

$H_{l c}$ : Government bonds can act as a safe haven for the Singapore Stock Exchange.

$H_{l d}$ : Government bonds can act as a safe haven for the Philippines Stock Exchange.

$H_{l e}$ : Government bonds can act as a safe haven for the Thailand Stock Exchange.

\section{Corporate Bonds as a Safe Haven}

During a shock to the market, corporate bonds tend to induce a negative response toward other assets, thus failed to perform as a safe instrument (Yunus, 2020). Contradicting, analysed the capital market of Indonesia and Malaysia, Robiyanto (2018b) suggested investors to invest in corporate bonds as both hedge and safe haven. Based on the above explanation, some further hypotheses are formulated as:

$H_{2 a}$ : Corporate bonds can act as a safe haven for the Indonesian Stock Exchange.

$H_{2 b}$ : Corporate bonds can act as a safe haven for the Kuala Lumpur Stock Exchange.

$\mathrm{H}_{2 \mathrm{c}}$ : Corporate bonds can act as a safe haven for the Singapore Stock Exchange.

$H_{2 d}$ : Corporate bonds can act as a safe haven for the Philippines Stock Exchange.

$H_{2 e}$ : Corporate bonds can act as a safe haven for the Thailand Stock Exchange.

\section{Research Method}

The data used in this study include closing price of stocks, government bonds and corporate bonds in a daily observation. The ASEAN-5 stock prices were taken from The Wall Street Journal (wsj.com) consist of JCI (Jakarta Composite Index), KLSE (Kuala Lumpur Stock Exchange), STI (Straits Times Index), SET 
(Stock Exchange of Thailand) and PSEi (Philippines Stock Exchange). The data of corporate and government bonds were taken from S\&P Dow Jones Indices LLC, namely: S\&P Indonesian Corporate Bond Index (ICB), S\&P Indonesian Government Bond Index (IGB), S\&P Malaysian Corporate Bond Index (MCB), S\&P Malaysian Government Bond Index (MGB), S\&P Singapore Government Bond Index (SGB), S\&P Singapore Corporate Bond Index (SCB), S\&P Philippines Government Bond Index (PGB), S\&P Philippines Corporate Bond Index (PCB), Thailand Government Bond Index (TGB), and S\&P Thailand Corporate Bond Index (TCP). Each bond indexes are dedicated in each country's local currency.

\section{Variables}

Revolving on Robiyanto (2018b), the followings are the definitions of operational variables in this research. The market returns are calculated as following:

$$
R_{S P I, c, t}=\left[\frac{S P I_{t}-S P I_{t-1}}{S P I_{t-1}}\right]
$$

Where the $S P I_{t}$ represents the closing price index in the market under study in country c on the day $t . S P I_{t-1}$ is the closing price index in the market under study in day $t-1$.

\section{Analysis Technique}

This study applied GARCH estimation to examine the potency of bonds as a hedge. The GARCH formula used is as follows:

$$
R_{\text {instrument }}=\alpha+\beta_{1} R_{\text {Index }}+\varepsilon t
$$

With, $\varepsilon_{t}=$ residual terms, $R_{\text {instrument }, t}=$ return on ASEAN's government and corporate bonds, $R_{\text {Index }}=$ return on ASEAN's closing price stock indexes.

Quantile regression method was applied to clarify the dependencies between variables and tends to have higher accuracy of revealing the distribution of returns and the accuracy of variable's relationship according to market conditions (Bouoiyour, Selmi, \& Wohar, 2018; Miyazaki, 2019).

QREG equation used to test whether bonds could act as a robust safe haven is as follows:

$$
\begin{aligned}
R_{\text {instrument }}= & \alpha+\beta_{1} R_{S P I}(50 \%, 40 \%, 30 \%, 20 \%, 10 \%) \\
& +\varepsilon t
\end{aligned}
$$

With, $\varepsilon_{t}=$ residual terms, $R_{\text {instrument }, t}=$ return on ASEAN's government and corporate bonds, = return on ASEAN's closing stock price indexes for quantile of 50 percent, 40 percent, 30 percent, 20 percent and 10 percent.

\section{Result and Discussion}

The empirical investigation starts with heteroscedasticity test as indicated in Table 1 . The result of Glejser test (OLS) indicates a heteroscedasticity. Thus, in order to vanquished the heteroscedasticity, GARCH estimation model is needed by applying Gaussian and GED model. The best model is will be presented by the smallest value of AIC (Akaike Information Criterion). Finally, we found that the GED-GARCH model is the best fit to out samples, as it captures the fat tails observed in the distribution of financial time series.

\begin{tabular}{|c|c|c|c|}
\hline & \multirow{2}{*}{ OLS } & \multicolumn{2}{|c|}{ GARCH (1.1) } \\
\hline & & Gaussian & GED \\
\hline \multirow[t]{3}{*}{ ICB } & -0.732335 & 21.02253 & 2.432678 \\
\hline & $(0.4657)$ & $(0.0000)$ & $(0.0150)$ \\
\hline & {$[-9.5844]$} & {$[-9.4471]$} & {$[-9.5741]$} \\
\hline \multirow[t]{3}{*}{ IGB } & -0.495783 & 5.890651 & 3.373393 \\
\hline & $(0.62111)$ & $(0.000)$ & $(0.0002)$ \\
\hline & {$[-8.43904]$} & {$[-8.2631]$} & {$[-8.3050]$} \\
\hline \multirow[t]{3}{*}{ MCB } & 1.229599 & -3.439856 & 0.119338 \\
\hline & $(0.2217)$ & $(0.0006)$ & $(0.9050)$ \\
\hline & [-10.4478] & [-11.202] & [-11.680] \\
\hline \multirow[t]{3}{*}{ MGB } & 0.641881 & -1.717330 & 5.317044 \\
\hline & $(0.5224)$ & $(0.0859)$ & $(0.0000)$ \\
\hline & [-8.66264] & [-8.8577] & [-9.6273] \\
\hline \multirow[t]{3}{*}{ PCB } & 0.126405 & -2.363827 & 0.063788 \\
\hline & $(0.8997)$ & $(0.0181)$ & $(0.9491)$ \\
\hline & {$[-10.2374]$} & {$[-9.8453]$} & [-9.9430] \\
\hline \multirow[t]{3}{*}{ PGB } & 0.453909 & -1.551581 & -0.43443 \\
\hline & $(0.6509)$ & (0.1208) & $(0.6640)$ \\
\hline & [-8.68349] & {$[-8.1676]$} & [-8.6438] \\
\hline \multirow[t]{3}{*}{ TGB } & -0.846719 & -3.203621 & -3.33679 \\
\hline & $(0.3992)$ & $(0.0014)$ & $(0.0008)$ \\
\hline & [-9.71213] & {$[-9.9330]$} & {$[-10.110]$} \\
\hline \multirow[t]{3}{*}{ TCB } & -0.439105 & -0.875424 & -1.38649 \\
\hline & $(0.6615)$ & $(0.3813)$ & $(0.1656)$ \\
\hline & {$[-9.27406]$} & {$[-9.6886]$} & {$[-9.7662]$} \\
\hline \multirow[t]{3}{*}{ SCB } & 1.512532 & -2.714219 & -2.64340 \\
\hline & $(0.1336)$ & $(0.0066)$ & $(0.0082)$ \\
\hline & [-11.2078] & {$[-10.808]$} & {$[-10.926]$} \\
\hline \multirow[t]{3}{*}{ SGB } & -3.896361 & -8.644007 & -6.78478 \\
\hline & $(0.0002)$ & $(0.0000)$ & $(0.0000)$ \\
\hline & {$[-10.0355]$} & {$[-10.172]$} & {$[-10.354]$} \\
\hline
\end{tabular}

Table 1

Glejser Test Result for OLS and GARCH in Significance Variance

\section{Safe Haven, Diversifier and Hedge Capabilities of Bonds}

Table 2 presented the performance of bonds as a safe haven, diversifier and hedge. Following (Bouri, Molnár, Azzi, Roubaud, \& Hagfors, 2017), a strong safe haven is regarded as an asset, when the global financial market worsened, is negatively correlated 
Table 2

Quantile Regression Test Result of ASEAN-5

\begin{tabular}{|c|c|c|c|c|c|c|}
\hline & \multirow{2}{*}{ GARCH-GED } & \multicolumn{5}{|c|}{ Quantile } \\
\hline & & 0.5 & 0.4 & 0.3 & 0.2 & 0.1 \\
\hline \multicolumn{7}{|c|}{ Panel A: Indonesia } \\
\hline ICB & $\begin{array}{r}0.065466^{* * * *} \\
(21.02253)\end{array}$ & $\begin{array}{r}0.061407 \\
(1.130035)\end{array}$ & $\begin{array}{r}0.022084 \\
(1.557750)\end{array}$ & $\begin{array}{c}0.025880^{*} \\
(1.711495)\end{array}$ & $\begin{array}{r}0.019928 \\
(1.286134)\end{array}$ & $\begin{array}{r}0.022574 \\
(1.132913)\end{array}$ \\
\hline IGB & $\begin{array}{r}0.100044 * * * \\
\quad(5.890651)\end{array}$ & $\begin{array}{r}0.062314 \\
(1.227578)\end{array}$ & $\begin{array}{l}0.085954 * \\
(1.831134)\end{array}$ & $\begin{array}{r}0.089421 \\
(2.181362)\end{array}$ & $\begin{array}{r}0.112448 * * * \\
\quad(2.941899)\end{array}$ & $\begin{array}{r}0.142741 * * * \\
(10.89613)\end{array}$ \\
\hline \multicolumn{7}{|c|}{ Panel B: Malaysia } \\
\hline MCB & $\begin{array}{r}-0.01104 * * * \\
(-3439856)\end{array}$ & $\begin{array}{r}0.002648 \\
(0.436632)\end{array}$ & $\begin{array}{r}-6.03 E-05 \\
(-0.010644)\end{array}$ & $\begin{array}{r}2.734505 \\
(-0.01064)\end{array}$ & $\begin{array}{r}5.01 \mathrm{E}-0.6 \\
(0.000887)\end{array}$ & $\begin{array}{r}0.02250^{* * * *} \\
(3.102142)\end{array}$ \\
\hline MGB & $\begin{array}{l}-0.028164^{*} \\
(-1.717330)\end{array}$ & $\begin{array}{l}0.0012978 \\
(0.686696)\end{array}$ & $\begin{array}{r}0.007654 \\
(0.424968)\end{array}$ & $\begin{array}{r}0.015493 \\
(0.705802)\end{array}$ & $\begin{array}{r}0.036539 \\
(0.916423)\end{array}$ & $\begin{array}{r}0.046283 * * \\
(2.090048)\end{array}$ \\
\hline \multicolumn{7}{|c|}{ Panel C: Philippines } \\
\hline PCB & $\begin{array}{r}-0.009515^{* *} \\
(-2.363827)\end{array}$ & $\begin{array}{r}0.002266 \\
(0.011025)\end{array}$ & $\begin{array}{r}0.001470 \\
(0.149159)\end{array}$ & $\begin{array}{r}-0.006461 \\
(0.979411)\end{array}$ & $\begin{array}{r}-0.002708 \\
(-0.464167)\end{array}$ & $\begin{array}{r}0.010513 \\
(1.488910)\end{array}$ \\
\hline PGB & $\begin{array}{r}-0.014394 \\
(-1.551581)\end{array}$ & $\begin{array}{r}0.005803 \\
(0.327331)\end{array}$ & $\begin{array}{r}-0.001072 \\
(-0.053712)\end{array}$ & $\begin{array}{l}-0.000133 \\
(-0.00602)\end{array}$ & $\begin{array}{r}0.006783 \\
(0.426054)\end{array}$ & $\begin{array}{r}0.010513 \\
(1.488910)\end{array}$ \\
\hline \multicolumn{7}{|c|}{ Panel D: Thailand } \\
\hline TCB & $\begin{array}{r}-0.01308 * * * \\
(-3.203621)\end{array}$ & $\begin{array}{l}-0.015800 \\
(-1.31955)\end{array}$ & $\begin{array}{l}-0.0019060 \\
(-1.650454)\end{array}$ & $\begin{array}{r}-0.013554 \\
(0.927312)\end{array}$ & $\begin{array}{r}-0.009502 \\
(-0.526927)\end{array}$ & $\begin{array}{r}-0.008043 \\
(-0.215823)\end{array}$ \\
\hline TGB & $\begin{array}{r}-0.006139 \\
(-0.875424)\end{array}$ & $\begin{array}{l}-0.014957 \\
(-0.87745)\end{array}$ & $\begin{array}{r}-0.009645 \\
(-0.560515)\end{array}$ & $\begin{array}{r}-0.0003619 \\
(-0.18821)\end{array}$ & $\begin{array}{r}0.007996 \\
(0.328266)\end{array}$ & $\begin{array}{r}0.002033 \\
(0.062119)\end{array}$ \\
\hline \multicolumn{7}{|c|}{ Panel E: Singapore } \\
\hline SCB & $\begin{array}{r}-0.014338 * * * \\
(-2.714219)\end{array}$ & $\begin{array}{r}-0.007665 \\
(-0.596444)\end{array}$ & $\begin{array}{l}-0.010724 \\
(-0.77996)\end{array}$ & $\begin{array}{l}-0.011236 \\
(-0.63901)\end{array}$ & $\begin{array}{r}-0.003409 \\
(-0.172323)\end{array}$ & $\begin{array}{r}-0.02022 * * * * \\
(-3.87419)\end{array}$ \\
\hline SGB & $\begin{array}{r}-0.042602 * * * \\
(-8.644007)\end{array}$ & $\begin{array}{l}-0.03017 * * \\
(-2.497255)\end{array}$ & $\begin{array}{l}-0.02210^{*} \\
(-1.90528)\end{array}$ & $\begin{array}{l}-0.018694 \\
(-1.58764)\end{array}$ & $\begin{array}{r}-0.010499 \\
(1.143034)\end{array}$ & $\begin{array}{r}-0.005228 \\
(0.687916)\end{array}$ \\
\hline
\end{tabular}

Source: Various sources, processed

Notes: *, **, *** indicate the levels of significance at $10 \%, 5 \%$, and $1 \%$

with other portfolios and often statistically insignificant. While over time, hedges classified with having no correlation or negative correlated with other assets and diversifiers is having a positive and significant correlation.

As shown in Panel A, both Indonesia corporate government (ICB) and Indonesia government bond (IGB) shows a positive significant sign of OLS. Meaning, bonds of Indonesia may serve as a diversifier towards Indonesia's stock market. Supported by the positive result of quantile regression, both ICB and IGB are failed to serve as a safe haven.

Similar result was found for Malaysia (Panel B) and Philippines bonds (Panel C). The result of regression test for MCB and MGB shows a positive result while the OLS provide a negative sign. Even though almost all quantiles of PCB and PGB signify a negative sign, the smaller quantiles show a positive sign. Means, the stronger the prices fall, the weakening bonds maintaining its value. Thus, bonds for both Malaysia and Philippines are able to be regarded as a hedge, but not a safe haven.
This finding indicates that there is a positive comovement between stock and bonds in Indonesia, Malaysia, and Philippines. When shock to the market arise, the price of stocks falls and followed with the decline of bond's return. Study conducted by Hussain Shahzad, Raza, Shahbaz, and Ali (2017) found that the dependencies of stock-bonds is positive during an extreme bearish market. This condition may occur due to the high dependencies of developing countries toward foreign investment (Ridha \& Budi, 2020) which explained the volatility in bonds yield as the increase of foreign ownership (Ebeke \& Lu, 2015). The experience of market crisis appears to have made both local and foreign investors focused on the shortcoming for government and corporate bonds. Based on the data from Central Bank of Indonesia (www.bi.go.id), as of March 2020, there is a massive capital outflow in Indonesia as the worsened spread of COVID-19 disease. With the total of IDR 105.1 billion of foreign capital began flowing out including stocks with total value of IDR 8.3 billion, IDR 92.8 billion of government bonds and the rest is corporate bonds. 
Corporate bond of Thailand (TCB) shows a negative sign of regression, meaning that TCB are able to perform as a strong safe haven (Panel D). Meanwhile, government bond of Thailand (TGB) cannot be regarded as a strong safe haven. The quantile of TGB result shows a negative sign in the percentage of 50, 40, and 30, and becomes positive in the lower quantile percentages. Even so, The OLS result shows that Thailand government and corporate bonds are able to serve as a hedging instrument. The failure of government bonds as a safe haven is consistent with the study undertaken by (Robiyanto, 2018b). A global sell-offs in longer-dated government bonds hits Thailand market severely, resulting a 17\% decline of stock index for the year. To asses this risk, the Bank of Thailand engaged in bond purchase to provide liquidity and ensure normal functioning of government and corporate bond market (19/03/2020).

Meanwhile, both government and corporate bonds of Singapore confirming a strong indication of becoming an oasis of safety. Panel E indicate a negative quantile correlation in all percentages for both SCB (Singapore corporate bond) and SGB (Singapore government bond). Means, as the market became more uncertain, Singapore bonds shows its existence as a safe haven for Straight Times Index (STI).

The ability of bond as a secure asset is align with the study done by Hussain Shahzad et al. (2017). He argued that in the lower quantile ( $\leq 40$ percent), developed countries such as U.S., German and Japan ought to perform a negative dependency between stocks and bonds. One of the prominent evidences, a structured financial system and macroeconomic stability tends to allows interest rate to be market-driven, thus increasing the demand of bonds. Studying the effectiveness of government bonds as a safe haven, Liu (2018) suggested Singapore government bond to be a favourable instrument during market turmoil. Hereby, the investors in Singapore tend to trust both government bonds and corporate bonds to secure their investment during the global health crisis.

Finally, the hedging effectiveness of corporate bonds and government of ASEAN stock market tend to diminish as the market rates drop significantly. Thus, investors in Indonesia could use bonds as a diversification instrument, while a hedge for Malaysia and Philippines. Among other countries, government bond and corporate bonds of Singapore become the most favourable safe assets as it offers relatively stable returns in a risk averse environment.

\section{Diagnostic Performance}

Both CUSUM Test (Figure 1) and Augmented Dickey-Fuller test (Table 3) are not showing any violation of the data. Means, the data is passing the stability and stationary test.

Table 3

Augmented Dickey-Fuller (ADF) Test Result

\begin{tabular}{ccc}
\hline Variable & ADF Statistics & Probability \\
\hline JCI & -9.330943 & 0.00000 \\
KLSE & -8.549984 & 0.00000 \\
STI & -9.781923 & 0.00000 \\
PSEI & -9.399259 & 0.00000 \\
SET & -11.53595 & 0.00000 \\
ICB & -8.059264 & 0.00000 \\
MCB & -6.154399 & 0.00000 \\
SCB & -7.622873 & 0.00000 \\
PCB & -5.628622 & 0.00000 \\
TCB & -9.591197 & 0.00000 \\
IGB & -7.802290 & 0.00000 \\
MGB & -6.475560 & 0.00000 \\
SGB & -9.036546 & 0.00000 \\
PGB & -6.18031 & 0.00000 \\
TGB & -11.53595 & 0.00000 \\
\hline
\end{tabular}

\section{Normality Test}

The normality test is conducted by using JarqueBera models. The result in Table 3 shows that all data are not normally distributed. Thus, skewed error distribution assumption (GED) is used to outperform the abnormality of the data. A noted from Abdul Rahim, Zahari, and Shariff (2017), a Generalized Error Distribution (GED) assumption can provide more efficient models and the characteristics of heteroscedastic error can be presented in more precise manner.

Table 4

Normality Test

\begin{tabular}{ccc}
\hline Item & $\boldsymbol{P}$ Value & Conclusion \\
\hline JCI & 0.000 & Not Normally Distributed \\
KLSE & 0.000 & Not Normally Distributed \\
STI & 0.000 & Not Normally Distributed \\
PSEI & 0.000 & Not Normally Distributed \\
SET & 0.000 & Not Normally Distributed \\
ICB & 0.000 & Not Normally Distributed \\
IGB & 0.000 & Not Normally Distributed \\
MCB & 0.000 & Not Normally Distributed \\
MGB & 0.000 & Not Normally Distributed \\
SCB & 0.000 & Not Normally Distributed \\
SGB & 0.000 & Not Normally Distributed \\
PCB & 0.000 & Not Normally Distributed \\
PGB & 0.000 & Not Normally Distributed \\
TCB & 0.000 & Not Normally Distributed \\
TGB & 0.000 & Not Normally Distributed \\
\hline
\end{tabular}

Table 4 presented the autocorrelation diagnostic using Q-statistics in the correlogram of residuals. The market of Malaysia, Singapore government bonds, 
$\underline{\text { ICB }}$

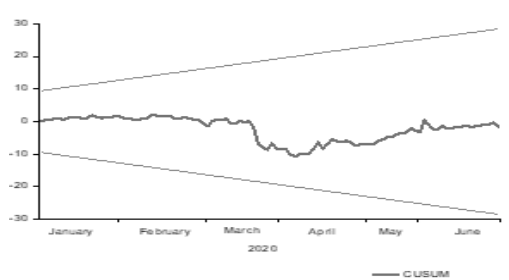

$\underline{\mathbf{P C B}}$

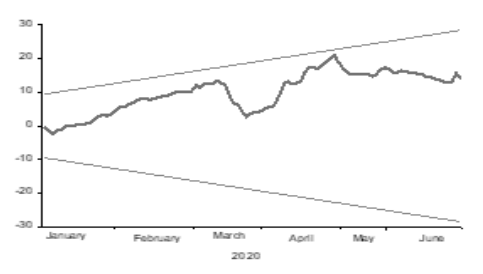

$\underline{\text { TCB }}$

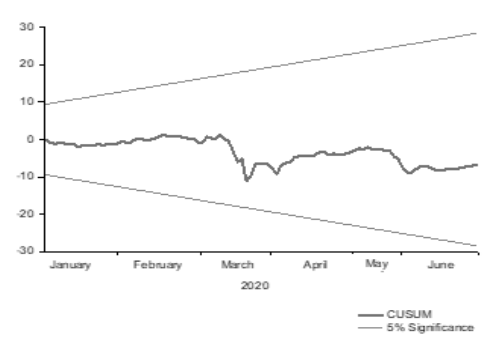

Figure 1. CUSUM Test Result for OLS

Table 5

Autocorrelation Test Result (Correlogram)

\begin{tabular}{lccccccc}
\hline & \multirow{2}{*}{ OLS } & GED & \multicolumn{5}{c}{ Quantile } \\
\cline { 4 - 8 } & & $\mathbf{0 . 5}$ & $\mathbf{0 . 4}$ & $\mathbf{0 . 3}$ & $\mathbf{0 . 2}$ & $\mathbf{0 . 1}$ \\
\hline ICB & None & None & None & None & None & None & None \\
IGB & None & None & None & None & None & None & None \\
MCB & 4 & 13 & 4 & 5 & 5 & 2 & 2 \\
MGB & None & None & 3 & 3 & 2 & 1 & 1 \\
SCB & 36 & 34 & 36 & 36 & 36 & 36 & 36 \\
SGB & None & None & None & None & None & None & None \\
PCB & 34 & None & 36 & 36 & 36 & 36 & 28 \\
PGB & 4 & None & 5 & 7 & 7 & 5 & 7 \\
TCB & None & None & None & None & None & None & None \\
TGB & 6 & None & 9 & 8 & 6 & 3 & 5 \\
\hline
\end{tabular}

Philippines corporate bonds, and Thailand government bonds tends to suggest that the model is miss-specified and in some sense that there are key variables are $\underline{\text { IGB }}$

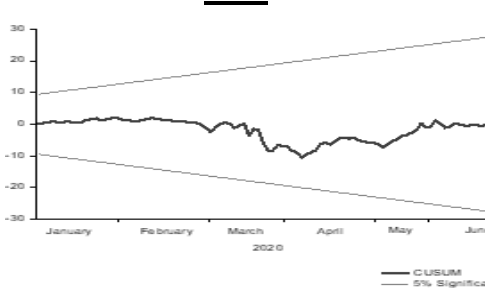

PGB

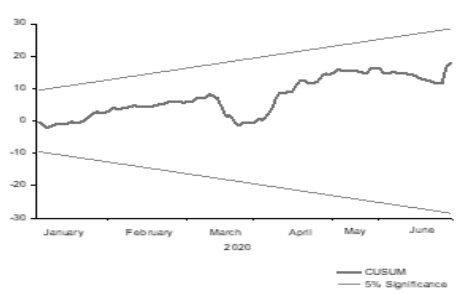

$\underline{\text { TGB }}$

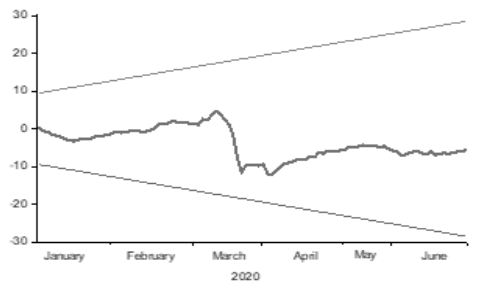

二 cusum

$\underline{\text { SGB }}$

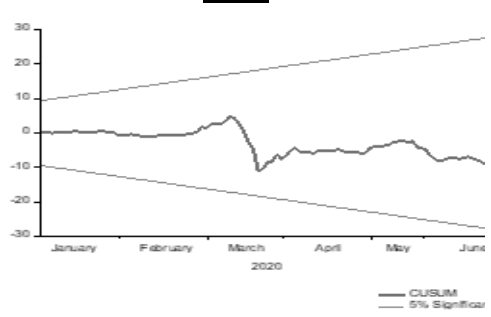

$\underline{\mathrm{MCB}}$

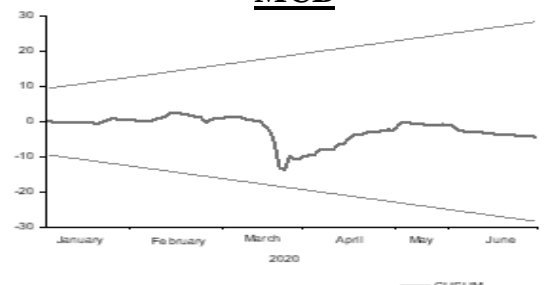

$\underline{\text { MGB }}$

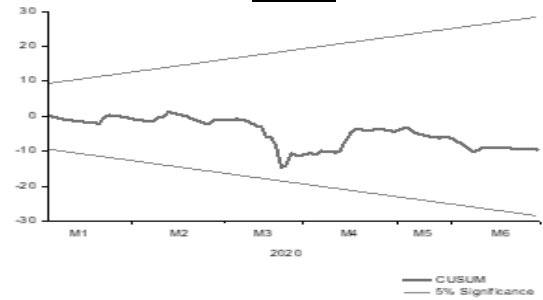

$\underline{\text { SCB }}$

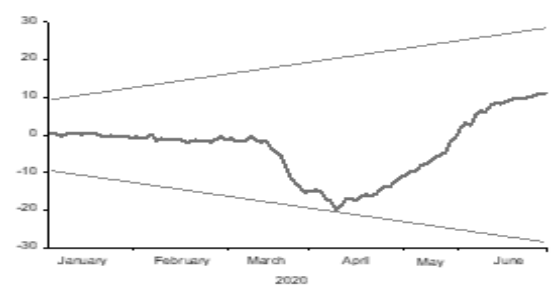

- cussum missing. To anticipate this error, a certain method is applied named GARCH (Generalized Autoregressive Conditional Heteroscedasticity). 


\section{Robustness Test Result}

Table 6 provide the information of robustness models by applying Theil coefficient measurement. In preference to Mackay and Bliemel (2014), the preferable model of robustness showed in a smaller Theil coefficient. As the coefficient lies between one to zero, the perfect fit would be the time when the coefficient equals to zero.

\section{Table 6}

\section{Theil Coefficient}

\begin{tabular}{|c|c|c|c|c|c|c|}
\hline \multirow{2}{*}{\multicolumn{2}{|c|}{ GED }} & \multicolumn{5}{|c|}{ Quantile } \\
\hline & & 0.5 & 0.4 & 0.3 & 0.2 & 0.1 \\
\hline$\overline{\mathrm{ICB}}$ & 0.78 & 0.78 & 0.79 & 0.79 & 0.80 & 0.73 \\
\hline MCB & 0.81 & 0.78 & 0.85 & 0.89 & 0.94 & 0.80 \\
\hline PCB & 0.85 & 0.83 & 0.95 & 0.88 & 0.81 & 0.76 \\
\hline TCB & 0.80 & 0.81 & 0.82 & 0.85 & 0.82 & 0.73 \\
\hline SCB & 0.74 & 0.76 & 0.82 & 0.83 & 0.79 & 0.74 \\
\hline IGB & 0.68 & 0.71 & 0.67 & 0.66 & 0.63 & 0.64 \\
\hline MGB & 0.81 & 0.91 & 0.95 & 0.92 & 0.83 & 0.75 \\
\hline PGB & 0.94 & 0.86 & 0.97 & 0.93 & 0.87 & 0.79 \\
\hline TGB & 0.82 & 0.81 & 0.89 & 0.91 & 0.80 & 0.74 \\
\hline SGB & 0.71 & 0.73 & 0.79 & 0.85 & 0.83 & 0.78 \\
\hline
\end{tabular}

According to Table 6, the GED models of IGB has the smallest Theil coefficient for ASEAN-5 capital market. This finding does not mean that Indonesia government bonds is a robust safe haven, as the regression of JCI is positive in all quantiles. This indicates that smaller quantile will lead to less fit models as IGB tends to become a diversifier over time. Meanwhile, for the corporate bond, SCB has the lowest Theil coefficient. The coefficient is decreasing gradually suggesting the more severe financial market conditions will lead to a better fit. As the lower quantiles of STI shows a consistent negative sign, this shows that corporate bonds can act as a safe haven for the Singapore capital market.

\section{Conclusion and Implication}

Our primary result in this part of empirical analysis is that the bonds market continues to play its traditional role as a hedge for equity market at least on average. Bond are only act as a diversifier in Indonesia capital market while becoming a hedge for Malaysia and Philippines capital market. Meaning, both corporate bond and government bond in Indonesia, Malaysia and Philippines tend to have a co-movement with the stock prices. In line with this study, however, in times of crisis, corporate bonds of Singapore and Thailand plays a strong function as a safe haven.
Meanwhile, for government bonds, Singapore government bonds are the only instrument that are able to act as a strong save haven when stock prices drop significantly.

Finally, as COVID-19 crashing the market into a loop, investors in Singapore and Thailand should add more corporate bonds into their portfolios as it is proven to be a strong safe haven. The government bonds of Singapore showed positive returns during the pandemic of COVID-19, indicating that they are able to be labelled as a safe haven asset. Thus, due to the expected return, investors in Singapore suggested to keep investing in both corporate and government bonds. Meanwhile, the hedging effectiveness of corporate bonds and government bonds in Indonesia, Malaysia and Philippines in a stock-dominated portfolio tend to diminish as the market rates drop significantly. Thus, investors in Indonesia could use bonds as a diversification instrument, while a hedging instrument for Malaysia and Philippines.

While we concentrate on bonds in ASEAN-5, it would be interesting to extend our analysis into a broader scope of time period and geographic zone. Slope factor suchlike long-term, medium-term, and short-term maturity of bonds is suggested to be an attractive research study in the future. Thus, greater attention in the future researches is still needed for corporate bonds and government bonds.

The key finding of this research is consequential especially for speculators in their decision making while taking long and short positions accordingly. These result assist investors, portfolio manager, and other business or government policy makers in formulating a resilient portfolio. Finally, this study assists policy makers (financial ministries, central banks, securities regulator, etc.) responsible in regulating bond market in their home country, making a favourable regulation toward both bond issuance and to the operations of local and foreign investment, and strengthen market infrastructure.

\section{References}

Abdul Rahim, M. A., Zahari, S. M., \& Shariff, S. S. R. (2017). Performance of variance targeting estimator (VTE) under misspecified error distribution assumption. Pertanika Journal of Science \& Technology, 25(2), 607-618.

Akhtaruzzaman, M., Boubaker, S., Lucey, B. M., \& Sensoy, A. (2020). Is gold a hedge or safe haven asset during COVID-19 crisis? SSRN Electronic Journal, June. https://doi.org/10.2139/ssrn. 3621 358. 
Al-Awadhi, A. M., Alsaifi, K., Al-Awadhi, A., \& Alhammadi, S. (2020). Death and contagious infectious diseases: Impact of the COVID-19 virus on stock market returns. Journal of Behavioral and Experimental Finance, 27, 1-5. https://doi.org/ 10.1016/j.jbef .2020.100326

Ashraf, B. N. (2020). Economic impact of government interventions during the COVID-19 pandemic: International evidence from financial markets. Journal of Behavioral and Experimental Finance, 27, 1-9. https://doi.org/10.1016/j.jb ef.2020. 100371.

Bekiros, S., Boubaker, S., Nguyen, D. K., \& Uddin, G. S. (2017). Black swan events and safe havens: The role of gold in globally integrated emerging markets. Journal of International Money and Finance, 73, Part B, 317-334. https://doi.org/10.10 16/j.jimonfin .2017.02.010

Bouoiyour, J., Selmi, R., \& Wohar, M. E. (2018). Measuring the response of gold prices to uncertainty: An analysis beyond the mean. Economic Modelling, 75, 105-116. https:// doi.org/10.1016/ j.econmod.2018.06.010

Bouri, E., Molnár, P., Azzi, G., Roubaud, D., \& Hagfors, L. I. (2017). On the hedge and safe haven properties of bitcoin: Is it really more than a diversifier? Finance Research Letters, 20, 192198. https://doi. org/10.1016/j.frl.2016.09.025

Bulut, L., \& Rizvanoghlu, I. (2019). Is gold a safe haven? International evidence revisited. SSRN Electronic Journal. https:// doi.org/10.2139/ssrn. 3344945

Burniske, C., \& White, A. (2017). Bitcoin: Ringing the bell for a new asset class. Retrieved from https ://research.ark-invest.com/hubfs/1_Download_ Files_ARK-Invest/White_Papers/Bitcoin-Ring ing-The-Bell-For-A-New-Asset-Class. pdf

Cheema, M. A., \& Szulczyk, K. R. (2020). The 2008 global financial crisis and COVID-19 pandemic: An examination of safe haven assets? Retrieved from https://www.arx.cfa/en/research/2020/05/ soc110520-covid-19-pandemic-and-its-influenceon-safe-havens/?s_cid=smo_ARX20weekly_ covid1920200514_tw

Ebeke, C., \& Lu, Y. (2015). Emerging market local currency bond yields and foreign holdings - A fortune or misfortune? Journal of International Money and Finance. https://doi.org/10.1016/ j.ji monfin .2015.07.006

Dicle, M. F., \& Levendis, J. D. (2017). Hedging market volatility with gold. Quantitative Finance and Economics, 1(3), 253-271. https://doi.org/ 10.3934/qfe.2 017.3.253
Ghazali, M. F., Lean, H. H., \& Bahari, Z. (2015). Sharia compliant gold investment in Malaysia: Hedge or safe haven? Pacific Basin Finance Journal, 34, 192-204. https://doi.org /10.1016/ j.pacfin.2014.12. 005

Giles, C., Greeley, B., \& Arnold, M. (2020). Global recession already here, say top economists. $\mathrm{Fi}$ nancial Times. https://www.ft.com/content/be73 2afe-6526-11 ea-a6cd-df28cc3c6a68

Gürtler, M., Hibbeln, M., \& Winkelvos, C. (2016). The impact of the financial crisis and natural catastrophes on CAT Bonds. Journal of Risk and Insurance, 83(3), 579-612. https://doi.org/10.111 $1 /$ jori. 12057

Habib, M. M., Stracca, L., \& Venditti, F. (2020). The fundamentals of safe assets. Journal of International Money and Finance, 102, 102119. https://doi.org/10. 1016/j.jimonfin.2019.102119

He, Z., Krishnamurthy, A., \& Milbradt, K. (2019). A model of safe asset determination. American Economic Review, 109(4), 1230-1262. https://doi.or $\mathrm{g} / 10.1257 / \mathrm{aer} .20160216$

Hou, A. J., Khrashchevskyi, I., \& Peltomäki, J. (2019). Hedge and safe haven investing with investment styles. Journal of Asset Management, 20(5), 351364. https://doi.org/10.1057/s41260-019-00 1273

Hussain Shahzad, S. J., Raza, N., Shahbaz, M., \& Ali, A. (2017). Dependence of stock markets with gold and bonds under bullish and bearish market states. Resources Policy, 52 (March), 308-319. https://doi.org/10.1016/ j.resourpo 1.2017.04.006.

Ji, Q., Zhang, D., \& Zhao, Y. (2020). Searching for safe-haven assets during the COVID-19 pandemic. International Review of Financial Analysis, 71, 1-10. https://doi.org/10.1016/j.irfa.2020.101 526

Kopyl, K. A., \& Lee, J. B. T. (2016). How safe are the safe haven assets? Financial Markets and Portfolio Management, 30 (4), 453-482. https://doi. org/10. 1007/s11408-016-02 77-5

Lim, D. J., \& Cooper, Z. (2015). Reassessing hedging: The logic of alignment in east Asia. Security Studies, 24(4), 696-727. https://doi.org/10.1080/ 09636412.2015.1103130

Lin, F. L., Yang, S. Y., Marsh, T., \& Chen, Y. F. (2018). Stock and bond return relations and stock market uncertainty: Evidence from wavelet analysis. International Review of Economics and Finance, 55, 285-294. https://doi.org/10.1016/j.ire f.2017.07.013

Liu, W. H. (2018). Are gold and government bond safe-haven assets? An extremal quantile regression analysis. International Review of $\mathrm{Fi}$ nance, 20(2), 451-483. https://doi.org/10.11 11/irfi.12232 
Mackay, D. B., \& Bliemel, F. (2014). Notes and communications Theil's forecast accuracy coefficient: A clarification. Journal of Marketing Research, 10(4), 444-446. https://pdfs.semanticscholar.org/cc66/033ed3047c1b3d5eb47d85ec5 2789b36324d.pdf

Miyazaki, T. (2019). Clarifying the response of gold return to financial indicators: An empirical comparative analysis using ordinary least squares, robust and quantile regressions. Journal of Risk and Financial Management, 12(33), 1-18. https://doi. org/10.3390/ jrfm12010033

Morales, L., \& Andreosso-O'Callaghan, B. (2020). Covid-19: Global stock markets "Black Swan." Critical Letters in Economics \& Finance, 1(1), 114.

Ridha, M. R., \& Budi, N. (2020). The effect of foreign direct investment, human development and macroeconomic condition on economic growth: Evidence from Indonesia. Journal of Indonesian Applied Economics, 8(2), 46-54.

Robiyanto, R. (2018b). Gold vs bonds: What is the safe haven for the indonesian and Malaysian capital market? Gadjah Mada International Journal of Business, 20(3), 277-302. https://doi.org/10.2214 6/gamaijb.27775.
Robiyanto, Wahyudi, S., \& Pangestuti, I. R. D. (2017). Testing commodities as save haven and hedging instrument on ASEAN's five stock markets. Jurnal Ekonomi Kuantitatif Terapan, 10, 231-238.

Shakil, M. H., Mustapha, I. M., Tasnia, M., \& Saiti, B. (2018). Is gold a hedge or a safe haven? An application of ARDL approach. Journal of Economics, Finance and Administrative Science, 23 (44), 60-76. https://doi.org/10.1108/JE FAS-032017-0052

Šperanda, I., \& Tršinski, Z. (2015). Hedging as a business risk protection instrument. Ekonomski Vjesnik: Review of Contemporary Entrepreneurship, Business, and Economic Issues, 28(2), 551565. https://doi.org/10.1080/13574809.2015.109 2378

Wen, X., \& Cheng, H. (2018). Which is the safe haven for emerging stock markets, gold or the US dollar? Emerging Markets Review, 35, 69-90. https://doi. org/ 10.1016/j.emema r.2017.12.006.

Yunus, N. (2020). Time-varying linkages among gold, stocks, bonds and real estate. Quarterly Review of Economics and Finance, 77, 165-185. https:// doi.org/10.1016/j.qref.202 0.01.015. 